\title{
Management of ankylosing spondylitis with infliximab
}

\author{
This article was published in the following Dove Press journal: \\ Open Access Rheumatology Research and Reviews \\ 17 June 2009 \\ Number of times this article has been viewed
}

\author{
Éric Toussirot ${ }^{1,2,3}$ \\ Ewa Bertolini' \\ Daniel Wendling ${ }^{1,2}$ \\ 'Rheumatology, University Hospital \\ Jean Minjoz, Besançon, France; \\ ${ }^{2}$ Equipe d'Accueil 3186 "Agents \\ pathogènes et Inflammation" \\ University of Franche-Comté, \\ Besançon, France; ${ }^{3} \mathrm{ClC}$ - Biotherapy, \\ St-Jacques Hospital, Besançon, France
}

Correspondence: Éric Toussirot Rheumatology, University hospital Jean Minjoz, Bd Fleming 25000 Besançon, France

Tel +33 $38166824 \mid$

$\mathrm{Fax}+33381668686$

Email etoussirot@chu-besancon.fr
Abstract: Ankylosing spondylitis (AS) is a systemic inflammatory rheumatic disease responsible for back pain, stiffness and progressive loss of functional capacity with limited therapeutic options. Regular physical exercises together with the use of nonsteroidal antiinflammatory drugs are the two recognized treatment options in AS. Infliximab is a chimeric anti-tumor necrosis factor- $\alpha$ monoclonal antibody that has been demonstrated to be highly effective in the treatment of AS, providing clinical amelioration at both axial and peripheral skeleton. Infliximab also improves quality of life, function, biological parameters (acute phase reactants) and inflammatory lesions of the spine as detected by magnetic resonance imaging. It is given at a $5 \mathrm{mg} / \mathrm{kg}$ dosage, as an infusion at weeks $0,2,6$, and every 6 to 8 weeks after. Open-label and placebo-controlled trials have well demonstrated its high level of efficacy, with an improvement of the disease activity of at least $50 \%$ in $60 \%-80 \%$ of patients. In a large placebo-controlled trial, Assessment in Ankylosing Spondylitis Response Criteria (ASAS20) responders were observed in $61.2 \%$ of patients receiving infliximab compared to $19.2 \%$ of patients under placebo. Long-term efficacy is maintained when infliximab is administered every 6-8 weeks. Consensus international guidelines for the initiation and the use of this expensive treatment are available. Some questions remain, including the long-term safety, in particular the risk of lymphoma, and the potential influence of infliximab on radiological progression which is not currently demonstrated. Despite these concerns, infliximab has revolutionized the management of AS and represents a considerable therapeutic advancement in this disabling disease.

Keywords: anti-TNF $\alpha$, infliximab, ankylosing spondylitis

\section{Introduction}

For the past ten years, the therapeutic management of ankylosing spondylitis (AS) has considerably changed. In fact, the introduction of anti-TNF $\alpha$ agents in AS provides new (and until now, unmet) therapeutic perspectives for the patients. This review analyzes the available data on clinical, radiological, and biological efficacy of infliximab, the first anti-tumor necrosis factor- $\alpha$ (anti-TNF $\alpha$ ) used in AS, and discusses its place in the treatment of AS. Some questions persist, notably whether this treatment has disease-controlling properties.

\section{Ankylosing spondylitis: The disease Clinical features}

Ankylosing spondylitis is a systemic and chronic inflammatory rheumatic disease of the axial skeleton (spine and sacroiliac joints). The disease mainly affects young male subjects, with onset of symptoms between the ages of 20 and 30 years. The rheumatological symptoms include inflammatory back pain, stiffness and restriction of spinal 
mobility, but also peripheral arthritis (oligoarthritis mainly affecting the lower limbs) and inflammation of entheseal structures (junction of tendon with periosteum and bone). Other symptoms are fatigue and some extraarticular manifestations such as acute anterior uveitis, aortic regurgitation and cardiac conduction disturbances, apical pulmonary fibrosis and in patients with longstanding disease, secondary amyloidosis. AS is also characterized by progressive spinal ankylosis and deformity. Specific radiographic findings in AS are sacroiliitis and bony bridgings of the vertebrae or syndesmophytes. ${ }^{1}$ Some patients have associated psoriasis or Crohn's disease. The spondylarthropathies ( $\mathrm{SpA}$ ) refer to a group of diseases sharing common clinical and radiological characteristics with AS. Included in this group are reactive arthritis, psoriatic arthritis, rheumatic manifestations of inflammatory bowel diseases (IBD) and undifferentiated SpA. ${ }^{2}$

\section{Pathogenesis}

The pathological processes explaining such lesions and clinical features are synovitis and enthesitis. At the sacroiliac joint level, a dense inflammatory cellular infiltrate has been found, containing both CD4+ and CD8+ T cells, macrophages and TNF $\alpha$ RNA messenger in a significant amount. ${ }^{3}$ In the same way, there are evidences for inflammatory lesions in entheseal structures, with oedema and inflammatory infiltrate, mainly composed of CD8+ T cells. ${ }^{4}$ In addition, the peripheral joint manifestations of AS are explained by synovial hyperplasia, with infiltration by $\mathrm{T}$ lymphocytes and activated macrophages, fibrosis, and prominent and tortuous vascularity. ${ }^{5}$ B lymphocytes are also observed, both in peripheral joints and zygapophyseal joints of the spine. ${ }^{6}$

The disease involves both genetic and environmental factors. ${ }^{7}$ Indeed, there is a strong association between AS and the human leukocyte antigen (HLA) Class I antigen B27 which is observed in $90 \%$ of the white AS population. Environmental factors involve certain urogenital and enteric bacteria, as suggested by HLA-B27-related reactive arthritis. Aberrant immune response or molecular mimicry have been proposed for explaining the pathophysiology of the disease and it is thought that $\mathrm{CD} 8+\mathrm{T}$ cells produce an abnormal immune response to bacterial agent and/or self antigen, restricted by HLA-B27. Recently, genetic factors outside the HLA region have been identified and include polymorphisms at different loci: interleukin-23 (IL-23) receptor, aminopeptidase regulator of TNF receptor shedding (ARTS), an aminopeptidase located at the endoplasmic reticulum, and IL-1 gene complex. ${ }^{8,9}$

\section{Epidemiology and impact of the disease}

The prevalence of the disease has been estimated to range between $0.1 \%$ and $1.1 \%$. A German study evaluating the prevalence of AS in German HLA-B27 blood donors estimated it at $1.9 \%$ of the Berlin population. ${ }^{10}$ An epidemiological study in France (EPIRHUM study) evaluated the rate of standardized prevalence of SpA to $0.30 \%$ and AS to $0.08 \% .^{11}$

Ankylosing spondylitis is a chronic progressive disease leading to a limited range of motion of the spine, a loss of functional capacity, a clinical feature increasing with disease duration. ${ }^{12}$ Some indicators of prognosis have been identified: the presence of extraarticular disease (uveitis), a hip involvement, the stage of the disease at the time of diagnosis, the degree of patient compliance, the level of socioeconomic status, and education. ${ }^{13,14}$ Thus, the disease has socioeconomic consequences, with a higher rate of days of sick leave, loss of work, and higher mortality compared to age- and sex-matched general population. ${ }^{15}$

\section{Assessment of the disease}

Ankylosing spondylitis is a chronic inflammatory disease and like other chronic rheumatic diseases, various domains can be evaluated and especially, pain, inflammation, function, mobility, fatigue, global assessment, quality of life, concomitant treatments, radiographic changes, and others. ${ }^{16}$ According to international experts in AS assessment (Assessment in Ankylosing Spondylitis [ASAS] working group), several domains have been selected and are considered as clinically important in assessing symptomatic outcome in AS: physical function, pain, spinal mobility, patient global assessment, spinal stiffness, fatigue, and inflammation. For each of these domains, there is a number of instruments which could be used (Table 1). Each of these instruments have the required properties ie, reliability, validity, reproductibility, and sensibility to changes and are commonly used in clinical trials for evaluating symptomatic or disease-modifying treatments in AS. ${ }^{16}$

The ASAS working group has defined criteria for evaluating symptomatic improvement in AS, using four of the five outcome domains ie, physical function, pain, patient global assessment and inflammation, and consists of an improvement by $20 \%$ and by 10 units (on a scale of $0-100 \mathrm{~mm}$ ) in each of the three domains with no worsening of the fourth. ${ }^{17}$ This defines the ASAS20 criteria of short term improvement in AS which could be compared to the American College of Rheumatology (ACR) 20 criteria of improvement used in rheumatoid arthritis (RA). 
Table I Specific instruments for each relevant domain in ankylosing spondylitis ${ }^{16}$

\begin{tabular}{ll}
\hline Domain & Instrument \\
\hline Function & BASFI or Dougados Functional Index \\
Pain & VAS, last week, spine at night and VAS, last week, spine, due to AS \\
Spinal mobility & Chest expansion and modified Schober and occiput to wall distance \\
Patient global assessment & VAS, last week \\
Stiffness & Duration of morning stiffness, spine, last week \\
Peripheral joints and entheses & Number of swollen joints (44 joint count); no preferred instrument for entheses \\
Acute phase reactants & ESR \\
Radiograph of the spine & Anteroposterior + lateral spine (lumbar + cervical) + X-ray pelvis (sacroiliac, hips) \\
Fatigue & No preferred instrument \\
\hline
\end{tabular}

Abbreviations: AS, ankylosing spondylitis; VAS, visual analog scale; BASFI, Bath Ankylosing Spondylitis Functional Index; ESR, erythrocyte sedimentation rate.

\section{Traditional therapeutic approach}

Regular physical exercise associated with the administration of nonsteroidal anti-inflammatory drugs (NSAIDs) is considered to be the cornerstone of therapeutic management in AS. ${ }^{18-20}$ Physical exercise may slow down the progression of functional disability and NSAIDs are considered as the gold standard in AS drug therapy. ${ }^{21,22}$ NSAIDs clearly demonstrated substantial relief of symptoms, pain and stiffness in patient with axial or peripheral disease. However, the main problem of NSAIDs is their poor gastrointestinal tolerability. Another problem is that NSAIDs are not enough effective in some cases. In addition, there are limited alternative therapeutic options. Indeed, second-line treatments such as sulfasalazine and methotrexate are poorly effective in AS, particularly in patients with axial disease or enthesitis. ${ }^{23,24}$ Leflunomide or anakinra do not work on axial symptoms as well. ${ }^{25,26}$ Pamidronate has been proposed in some NSAID refractory patients but studies gave contradictory results. ${ }^{27,28}$ Systemic corticosteroids are not effective in AS while local corticosteroid injections (in the sacroiliac joints or entheseal structures) may be helpful in some cases. ${ }^{29}$

Thus, before the introduction of TNF $\alpha$-blocking agents, medical treatment options in AS were limited and there was an unmet need for new therapeutic options. Anti-TNFo agents have revolutionized this therapeutic management.

\section{Infliximab}

\section{Rationale for targeting TNF $\alpha$ in AS}

$\mathrm{TNF} \alpha$ is a pro-inflammatory cytokine produced by monocytes/macrophages and activated T cells. It is responsible for lymphocyte activation, release of other cytokines (IL-1, IL-6), prostaglandins, and metalloproteinases. There are substantial data suggesting a role for TNF $\alpha$ in AS physiopathology. Indeed, TNF $\alpha$ RNA messenger has been found to be abundantly expressed in the sacroiliac joints from patients with $\mathrm{AS}^{3}$ and the serum levels of TNF $\alpha$ and other inflammatory cytokines have been found to be increased compared to patients with mechanical back pain..$^{30,31}$ In addition, patients with AS (and also SpA) have sub-clinical gut involvement with histological lesions resembling those in Crohn's disease. ${ }^{32}$ Anti-TNF $\alpha$ therapy was effective in Crohn's disease patients. ${ }^{33}$ Another argument for targeting TNF $\alpha$ in AS and SpA is supported by the results of clinical trial with thalidomide in AS, a drug interfering with the production of TNF $\alpha .^{34}$ Taken together, these data give the rationale for the use of TNF $\alpha$-targeting treatment in AS. ${ }^{35-38}$

\section{Structure and pharmacokinetic properties} Infliximab (Remicade ${ }^{\circledR}$; Centocor Ortho Biotech Inc., Horsham, PA) is a chimeric monoclonal antibody that is $75 \%$ human and $25 \%$ mouse and consists of the constant region of human IgG1 $\kappa$ coupled to the Fv region of highaffinity neutralizing murine anti-human $\mathrm{TNF} \alpha$ antibody. Its molecular size is $149 \mathrm{kDa}$. It binds to soluble TNFo monomers and trimers and membrane-bound $\mathrm{TNF} \alpha$ with high affinity, avidity, and specificity. Infliximab may promote both lysis of TNF $\alpha$-producing cells and $\mathrm{T}$ lymphocyte apoptosis. Infliximab also inhibits binding of soluble TNF $\alpha$ to TNF receptors and may dissociate $\mathrm{TNF} \alpha / \mathrm{TNF}$ receptor complexes. However, infliximab does not bind to lymphotoxin $\beta$. Infliximab is administered IV over at least two hours. The molecule has a half life of 8-12 days, although it has been detected in the serum 28 days after the infusion. 39,40

\section{Clinical efficacy of infliximab in ankylosing spondylitis}

Infliximab has been tested in AS and/or SpA in 10 studies, including seven open ${ }^{41-47}$ and three placebo-controlled 
trials $^{48-50}$ (Tables 2 and 3). These different trials enrolled between 11 and 279 patients. Patients received three infusions of infliximab $5 \mathrm{mg} / \mathrm{kg}$ at weeks 0,2 , and 6 (except in one Canadian study which administered infliximab $3 \mathrm{mg} / \mathrm{kg},{ }^{44}$ followed by a maintenance regimen every 6,8 , or 14 weeks in the extension or follow-up studies. ${ }^{51,52}$ The study duration ranged from 12 weeks to one year. All these studies assessed the effects of infliximab on clinical parameters (spinal pain, swollen and tender joint scores, entheseal count, Bath Ankylosing Spondylitis Disease Activity Index [BASDAI] and Bath Ankylosing Spondylitis Functional Index [BASFI], quality of life questionnaire) and laboratory tests (erythrocyte sedimentation rate [ESR], C-reactive protein [CRP]). In some studies, the primary outcome measures were the $50 \%$ improvement in the BASDAI index or the ASAS20 response for improvement. Imaging methods using dynamic MRI were used in two studies to evaluate the impact of the treatment on entheseal lesions, synovitis, and sacroiliitis. ${ }^{42,43}$
Open-lapel studies were conducted in different countries (Germany with 11 AS patients, Belgium with 21 SpA patients, France with 50 AS patients, Spain with 40 SpA patients, Canada with 21 AS patients, and Greece with 25 AS patients) (Table 2). Altogether, open-label studies showed that infliximab gave a dramatic improvement in all clinical and laboratory variables of AS patients. An improvement of at least $50 \%$ was achieved in up to $60 \%-80 \%$ of patients. The beneficial effects were observed early after the beginning of the treatment, within two weeks after the first infusion of infliximab. Both axial and peripheral symptoms but also enthesopathic manifestations improved. In the German study, symptoms recurred around six weeks after the three infliximab infusions. ${ }^{52}$ This led the authors to propose a six-week interval between infusions in the subsequent randomized controlled trial.

Placebo-controlled studies were subsequently designed and confirmed the remarkable efficacy of TNF $\alpha$-blocking agents in AS and SpA (Table 3).

Table 2 Open-label studies evaluating the efficacy of infliximab in patients with ankylosing spondylitis or spondylarthropathy: results of clinical studies

\begin{tabular}{|c|c|c|c|c|c|}
\hline $\begin{array}{l}\text { Author } \\
\text { (Country) } \\
\text { (Reference) }\end{array}$ & $\begin{array}{l}\text { Patients } \\
(\mathbf{N})\end{array}$ & $\begin{array}{l}\text { Mean age } \\
\text { Mean disease } \\
\text { duration }\end{array}$ & $\begin{array}{l}\text { Treatment } \\
\text { protocol }\end{array}$ & $\begin{array}{l}\text { Outcome } \\
\text { parameters }\end{array}$ & Results \\
\hline $\begin{array}{l}\text { Brandt } \\
(\text { Germany })^{41}\end{array}$ & II AS & $\begin{array}{l}36 \\
5\end{array}$ & $\begin{array}{l}\text { IFX } 5 \text { mg/kg } \\
\text { Week } 0,2,6 \text { Follow up: } \\
12 \text { weeks }\end{array}$ & $\begin{array}{l}\text { Spinal pain (VAS) BASDAI, } \\
\text { BASFI, ESR, CRP, IL-6, SF-36, } \\
\text { MRI }\end{array}$ & $\begin{array}{l}\text { BASDAl improvement } \\
\text { by } 70 \% \text { at week } 4 \\
\text { and improvement } \\
\text { in all end-points }\end{array}$ \\
\hline 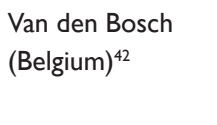 & $\begin{array}{l}21 \mathrm{SpA} \\
(10 \mathrm{AS})\end{array}$ & $\begin{array}{l}49 \\
17\end{array}$ & $\begin{array}{l}\text { IFX } 5 \mathrm{mg} / \mathrm{kg} \\
\text { Week } 0,2,6 \text { Follow up: } \\
12 \text { weeks }\end{array}$ & $\begin{array}{l}\text { Patient and physician global } \\
\text { assessment of disease activity, } \\
\text { BASDAI, BASFI, ESR,CRP, }\end{array}$ & $\begin{array}{l}\text { Improvement in all } \\
\text { end-points }\end{array}$ \\
\hline Stone (Canada) ${ }^{43}$ & $21 \mathrm{AS}$ & 37.98 .7 & $\begin{array}{l}\text { IFX } 5 \text { mg/kg } \\
\text { Week } 0,2,6 \text { Follow up: } \\
\text { I } 4 \text { weeks }\end{array}$ & $\begin{array}{l}\text { Spinal pain, patient and } \\
\text { physician global assessment } \\
\text { of disease activity, BASDAI, } \\
\text { BASFI, ESR, CRP }\end{array}$ & $\begin{array}{l}\text { More than } 60 \% \\
\text { improvement in BASDAI, } \\
\text { BASFI, HAQ, pain, fatigue, } \\
\text { acute phase reactants }\end{array}$ \\
\hline $\begin{array}{l}\text { Maksymowych } \\
(\text { Canada })^{44}\end{array}$ & $21 \mathrm{AS}$ & $\begin{array}{l}42.5 \\
13.8\end{array}$ & $\begin{array}{l}\text { IFX } 3 \mathrm{mg} / \mathrm{kg} \\
\text { Week } 0,2,6 \text { and the } \\
\text { every } 8 \text { weeks Follow } \\
\text { up: } 14 \text { weeks }\end{array}$ & $\begin{array}{l}\text { BASDAI, BASFI, BAS-G, } \\
\text { BASMI, ESR, CRP, MRI }\end{array}$ & $\begin{array}{l}\text { More than } 50 \% \\
\text { improvement in BASDAI }\end{array}$ \\
\hline $\begin{array}{l}\text { Breban } \\
\text { (France) }^{45}\end{array}$ & $50 \mathrm{AS}$ & $\begin{array}{l}\text { Median } 35 \\
\text { Median I3 }\end{array}$ & $\begin{array}{l}\text { IFX } 5 \mathrm{mg} / \mathrm{kg} \\
\text { Week } 0,26 \text { Follow up } \\
24 \text { weeks }\end{array}$ & $\begin{array}{l}\text { Fatigue, BASDAI, BASFI, global } \\
\text { pain, CRP, ASAS20 }\end{array}$ & $94 \%$ ASAS20 responders \\
\hline 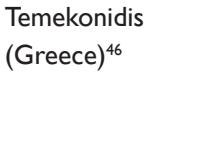 & 25 AS & $\begin{array}{l}36 \\
13.5\end{array}$ & $\begin{array}{l}\text { IFX } 5 \mathrm{mg} / \mathrm{kg} \\
\text { Week } 0,2,6 \text { and every } \\
8 \text { weeks for } 12 \text { months }\end{array}$ & $\begin{array}{l}\text { BASDAI, BASFI; patient global } \\
\text { assessment of pain, ESR, CRP }\end{array}$ & $\begin{array}{l}\text { Significant improvement in } \\
\text { BASDAI, CRP. Reduction } \\
\text { of patient global pain } \\
\text { by } 20 \% \text { in } 92 \%\end{array}$ \\
\hline $\begin{array}{l}\text { Collantes-Estevez } \\
(\text { Spain })^{47}\end{array}$ & $\begin{array}{l}40 \mathrm{SpA} \\
(34 \mathrm{AS})\end{array}$ & $\begin{array}{l}41 \\
16\end{array}$ & $\begin{array}{l}\text { IFX } 5 \mathrm{mg} / \mathrm{kg} \text { Week } 0,2 \text {, } \\
6 \text { and every } 8 \text { weeks } \\
\text { for } 38 \text { weeks }\end{array}$ & $\begin{array}{l}\text { BASDAI, BASFI, patient pain } \\
\text { assessment, quality of life, } 50 \% \\
\text { improvement in BASDAI }\end{array}$ & $\begin{array}{l}50 \% \text { improvement of } \\
\text { BASDAI in } 60 \% \text { of patients }\end{array}$ \\
\hline
\end{tabular}

Abbreviations: IFX, infliximab; BASDAI, Bath Ankylosing Spondylitis Disease Activity Index; BASFI, Bath Ankylosing Spondylitis Functional Index; BASMI, Bath Ankylosing Spondylitis Metrology Index; VAS, visual analog scale; HAQ, health assessment questionnaire; ESR, erythrocyte sedimentation rate; MRI, magnetic resonance imaging; ASAS, Assessment in Ankylosing Spondylitis group. 
- The group from Ghent published the results of a placebo controlled trial of infliximab treatment in a series of 40 active SpA patients (including 19 AS patients). ${ }^{49}$ Twenty patients received infliximab $5 \mathrm{mg} / \mathrm{kg}$ at weeks $0,2,6$, and every 8 weeks thereafter and 20 patients the placebo at the same interval. At week 12, there was a significant improvement of disease activity, physician global, patient global, peripheral arthritis and acute phase reactants in the infliximab group compared to the placebo group. Response to infliximab was seen already at week 2 . One patient under infliximab developed disseminated tuberculosis.

- Similar results were obtained in a 12 -week placebocontrolled study from the German group. ${ }^{48}$ Seventy patients participated to this trial, 35 receiving infliximab at weeks 0,2 , and 6 , and 35 received the placebo. The primary outcome was a $50 \%$ improvement of the BASDAI which was achieved at week 12 in $53 \%$ of the patients treated by infliximab and only $8 \%$ of the patients on placebo. The other results showed that quality of life (assessed by short from SF-36), physical function (assessed by BASFI), spinal mobility (assessed by Bath Ankylosing Spondylitis Metrology Index [BASMI]) significantly improved in the infliximab group. Peripheral arthritis and enthesitis also improved. The concentration of CRP in serum was identified as a probable indicator of response to infliximab since patients with high concentrations of CRP had the best rate of 50\% improvement in disease activity.

- The largest placebo-controlled trial with infliximab enrolled 279 patients (201 received infliximab $5 \mathrm{mg} / \mathrm{kg}$ and 78 received the placebo). ${ }^{50}$ Treatment was given at weeks $0,2,6$, and every 6 weeks over 24 weeks. The primary outcome parameter in this study was the proportion of patients with a $20 \%$ improvement response according to the ASAS criteria. At week 24, 61.2\% of patients in the infliximab group were ASAS20 responders compared to $19.2 \%$ in the placebo group. Other parameters (BASDAI, BASFI, BASMI, SF-36, number of swollen joints and acute phase reactants) improved similarly in the infliximab group. Similarly to other placebo-controlled studies, patients receiving infliximab showed significant improvement as early as week 2 and this response was maintained over the 24 week study.

\section{Efficacy of infliximab assessed by imaging}

The good clinical responses observed in the patients receiving infliximab paralleled the imaging amelioration as evaluated by magnetic resonance imaging (MRI). ${ }^{43,44}$ The modifications in MRI changes were observed at the different pathogenic levels of AS, ie, sacroiliac and peripheral joints and entheseal structures. In the German-controlled trial, MRI with STIR

Table 3 Randomized placebo-controlled trials evaluating the efficacy of infliximab in ankylosing spondylitis

\begin{tabular}{|c|c|c|c|c|c|}
\hline $\begin{array}{l}\text { Authors } \\
\text { (Country) } \\
\text { Reference) }\end{array}$ & Patients (N) & $\begin{array}{l}\text { Mean age } \\
\text { Mean disease } \\
\text { duration }\end{array}$ & Treatment protocol & Outcome parameters & Results \\
\hline $\begin{array}{l}\text { Braun } \\
(\text { Germany })^{48}\end{array}$ & $70 \mathrm{AS}$ & 39.815 .6 & $\begin{array}{l}\text { IFX } 5 \mathrm{mg} / \mathrm{kg} \text { or placebo } \\
\text { Week } 0,2,6 \text { follow up } \\
\text { I } 2 \text { weeks }\end{array}$ & $\begin{array}{l}\text { BASDAI, BASFI, BASMI, } \\
\text { quality of life }\end{array}$ & $\begin{array}{l}50 \% \text { improvement in } \\
\text { BASDAI: } 53 \% \text { (IFX) vs } \\
8 \% \text { (placebo) Significant } \\
\text { improvement in all end } \\
\text { points in the IFX group }\end{array}$ \\
\hline 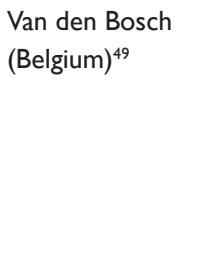 & $40 \mathrm{SpA}$ & 46.57 .2 & $\begin{array}{l}\text { IFX } 5 \mathrm{mg} / \mathrm{kg} \text { or placebo } \\
\text { Week } 0,2,6 \text { follow up } \\
\text { I } 2 \text { weeks }\end{array}$ & $\begin{array}{l}\text { Patient and physician } \\
\text { global assessment of } \\
\text { disease activity, ESR, CRP, } \\
\text { tender and swollen joint } \\
\text { counts, morning stiffness, } \\
\text { spinal pain, BASDAI, } \\
\text { BASFI }\end{array}$ & $\begin{array}{l}\text { Significant improvement } \\
\text { in all end points in the } \\
\text { IFX group }\end{array}$ \\
\hline $\begin{array}{l}\text { Van der Heijde } \\
\text { (international) }^{50}\end{array}$ & 279 AS & $\begin{array}{l}\text { 4I } \\
\text { II IFX I } 3.2 \text { Placebo }\end{array}$ & $\begin{array}{l}\text { IFX } 5 \mathrm{mg} / \mathrm{kg} \text { or placebo } \\
\text { week } 0,2,6,12 \text { and } 18 \\
\text { Follow up: } 24 \text { weeks }\end{array}$ & $\begin{array}{l}\text { ASAS20 responders } \\
\text { BASDAI, pain, BASFI, } \\
\text { BASMI, enthesis index, } \\
\text { swollen joint, CRP, SF-36 }\end{array}$ & $\begin{array}{l}\text { ASAS20 responders: } \\
61.2 \% \text { IFX vs } 19.2 \% \\
\text { placebo Significant } \\
\text { improvement in all } \\
\text { assessed variables in } \\
\text { the IFX group }\end{array}$ \\
\hline
\end{tabular}

Abbreviations: IFX, infliximab; BASDAI, Bath Ankylosing Spondylitis Disease Activity Index; BASFI, Bath Ankylosing Spondylitis Functional Index; BASMI, Bath Ankylosing Spondylitis Metrology Index; VAS, visual analog scale; ESR, erythrocyte sedimentation rate; ASAS, Assessment in Ankylosing Spondylitis group. 
sequences showed a significant regression by $60 \%$ of active spinal inflammatory lesions in the infliximab patients compared with $20 \%$ deterioration in the placebo group. ${ }^{53}$

Another imaging method to evaluate the efficacy of TNF $\alpha$ blockers in AS is ultrasonography: in two patients with refractory heel pain related to enthesopathic lesions at the insertion of the Achilles tendon and plantaris fascia, infliximab dramatically improved the symptoms. Inflammatory lesions were shown using power Doppler sonography and after infliximab administration, a progressive recovery of normal entheseal structures was observed in both patients. ${ }^{54}$

Ankylosing spondylitis is characterized by osteoporosis. ${ }^{55}$ It was demonstrated that bone mineral density (BMD) (assessed by dual energy X-ray absorptiometry [DEXA]) improved after six months of infliximab treatment in a series of 29 SpA patients: lumbar spine BMD increased by $3.6 \%$ and hip BMD by $2.2 \%{ }^{56}$

\section{Effects of infliximab on laboratory and immunological parameters}

In both open-label and placebo-controlled trials, it was evident that laboratory parameters of inflammation and ESR and CRP levels improved with a rapid decrease after starting the treatment. ${ }^{48-50}$

In addition, changes on cytokine profile were examined during infliximab therapy by means of circulating cytokine levels or intracellular cytokine protein expression in peripheral blood T cells. ${ }^{57}$ The circulating levels of TNF $\alpha$ or other inflammatory cytokine such as IL-6 were found to be increased in AS or SpA in general, as well as serum IL-10, an antiinflammatory cytokine. ${ }^{30,31}$ The changes in cytokine $\mathrm{T}$ cell expression during infliximab therapy was analyzed by Zou and colleagues. In this study, 10 patients with AS received infliximab at weeks 0,2 , and 6 . The percentage of CD4+ CD8+ T cells positive for intracellular TNF $\alpha$ and interferon- $\gamma($ IFN $\gamma$ ) was evaluated at baseline and at weeks 6 and 12. In these patients, infliximab induced a significant reduction in the number of CD4+ CD8+ T cells expressing TNF $\alpha$ and IFN $\gamma$, while there were no changes for IL-10 or IL-4 production. ${ }^{58}$ In addition, the same author analyzed the changes on cytokine $T$ cell expression after 12 weeks of etanercept (another TNF $\alpha$-blocking agent) administration. By contrast, the results did not show a downregulation of TNF $\alpha$ or IFN $\gamma$ but an increase in the percentage of CD4+ CD8+ T cells positive for these cytokines. ${ }^{59}$ The author explained their results by the fact that infliximab can downregulate Th1 cytokine while etanercept binds soluble TNF $\alpha$ and upregulates Th1 protein production after neutralization of peripheral
TNF $\alpha$. Different results were obtained in another study on the $\mathrm{T}$ cell cytokines in peripheral blood of SpA patients. ${ }^{60}$ Before infliximab treatment, patients with $\mathrm{SpA}$ were found to have an impaired Th1 cytokine profile compared with healthy controls and RA patients, as suggested by a decreased percentage of mononuclear cells positive for intracellular IFN $\gamma$ and IL-2. TNF $\alpha$ blockade induced restoration of Th1 cytokines with a significant and persistent increase in IFN $\gamma$ and IL-2. These data suggest that infliximab modifies the cytokine profile in $\mathrm{SpA}$ patients and can reverse a state of anergy of Th1 cells. Overall, these descriptions of cytokine protein expression in peripheral blood mononuclear cells during anti-TNF $\alpha$ therapy are not clear. This may reflect the complexity of cytokine regulation and may also be related to the artificial nature of stimulating cytokine expression before measurement.

Serum matrix metalloproteinase 3 (MMP-3) and macrophage colony-stimulating factor-1 (MCSF-1) were identified as laboratory parameters of disease activity in AS. ${ }^{61}$ In addition, serum MMP-3 is also an independent predictor of radiological progression in AS. ${ }^{62}$ When patients with AS were treated by inflixmab, serum MMP-3 decreased while there were no changes in the serum levels of MCSF-1. ${ }^{61}$ Another study found similar results with a decreased in serum MMP-3 in a series of 12 patients receiving infliximab. ${ }^{63}$

\section{Histological changes induced by infliximab administration in AS}

In the Ghent cohort was particularly examined the impact of infliximab on synovial tissue obtained by needle arthroscopy from inflamed peripheral joints. ${ }^{64}$ In eight patients (3 AS, 1 undifferentiated $\mathrm{SpA}, 4$ psoriatic arthritis) receiving infliximab was performed a series of knee synovial biopsies. Consecutive histological analysis of the synovial tissues showed that, after the treatment, the synovial lining thickness decreased with a reduction of the inflammatory infiltrate (neutrophils, macrophages, and also CD4+ T cells) and CD55+ fibroblast-like synoviocytes. A reduction of synovial vascularization and a decreased of endothelial expression of certain but not all adhesion molecules (vascular cell adhesion molecule-1 but not intracellular adhesion molecule-1 or Eselectin) were also observed. Of interest, the overall degree of cellular infiltrate did not change since neutrophils and CD68+ macrophages decreased while CD20+ lymphocytes and plasma cells increased. Another study found that the synovial expression of metalloproteinase MMP-3 and tissue inhibitor of matrix metalloproteases (TIMP-1) significantly decreased after infliximab treatment. ${ }^{63}$ 


\section{Long term efficacy of infliximab in AS}

The initial published studies reported the effects of infliximab on AS or SpA symptoms over a short period of 12 weeks. One study in Greece was conducted over a longer period (12 months). ${ }^{46}$

Data about long term treatment with infliximab in AS and $\mathrm{SpA}$ are now available: the Ghent open-label trial investigating the therapeutic potential of infliximab in SpA was extended to one year and the patients of the initial open trial were retreated every 14 weeks during one year. ${ }^{51}$ This study showed that the significant improvements of disease manifestations were all maintained without major side effect or loss of efficacy. The moment of recurrence of SpA symptoms was observed between 10 and 14 weeks after the last infusion, indicating that infliximab has a transient efficacy and therefore, the optimal maintenance regimen was certainly below this interval of time.

Prolonged infliximab efficacy has also been demonstrated in patients from the German study who went on to receive infliximab at a six-week interval for up to five years. ${ }^{52,65-67}$ After one year of therapy, $78 \%$ of patients were still being treated and around $50 \%$ of them still achieved $50 \%$ improvement in BASDAI score. ${ }^{52}$ After 2, 3, and 5 years, $70 \%, 62 \%$, and $55 \%$ continued treatment, respectively ${ }^{65-67}$ These studies confirm that long-term treatment with infliximab remains very efficacious in patients with active AS, with persistence of a low disease activity and durable clinical response in the different assessed variables (function, mobility, peripheral arthritis, enthesitis and quality of life). At two years, ASAS20 response was observed in $73 \%$ of patients. ${ }^{68}$

In another study from Greece, persistent clinical response was also observed in 35 patients with AS over a four-year period, with an infliximab survival rate of $77.9 \% .{ }^{69}$

Another cohort from Greece reported the same adherence to treatment after one $(94 \%)$ and two $(89 \%)$ years. ${ }^{70}$

In France, continuation of infliximab over time was also estimated in an open, observational two-year extension study after an open-label study of three infusions of treatment in refractory AS. Patients received infliximab infusions at a variable interval (mean: $11.6 \pm 9$ weeks), according to the rheumatologist opinion. At year 2, continuation rate was $74 \%{ }^{71}$

Thus, sustained clinical efficacy and high continuation rate over time were observed with prolonged infliximab treatment.

\section{Safety and tolerance}

Adverse events associated with infliximab treatment have been recently reviewed. ${ }^{72}$ The main safety concerns of infliximab are infusion reactions, infections, especially opportunistic infections including tuberculosis, development of auto-antibodies and auto-immune diseases, risk of lymphoma, and more rarely occurrence of demyelinating diseases and congestive heart failure. ${ }^{40,72}$ Placebo-controlled studies and long-term extensions of these studies, and postmarketing surveillance give important information on the adverse events of infliximab and other TNF $\alpha$ antagonists.

During the clinical trials with infliximab in AS, mild side effects were recorded including headache, dizziness, paresthesia, fatigue, upper respiratory infections (with a frequency which did not differ between infliximab and placebo), other minor infections (cystitis, sore throat, rhinitis, sinusitis, pharyngitis), abdominal pain, development of antinuclear antibodies in single patients. In general, there were no infusion reactions or delayed type hypersensitivity with infliximab infusions. In the controlled study by Braun, three serious adverse events were observed leading to withdrawal from the study: one case of systemic tuberculosis, one case of bronchocentric allergic granulomatosis, and one case of neutropenia. ${ }^{48}$ Maksymowych reported two serious adverse events: one septic osteomyelitis, and one case of severe hypersensitivity reaction. ${ }^{44}$ A Belgian controlled study observed one case of tuberculosis and one septic arthritis. ${ }^{49}$ During the one-year follow-up study of this cohort from Ghent, $57 \%$ of SpA patients developed antinuclear antibodies while anti-double stranded DNA occurred in $19 \%$ of these patients. ${ }^{51}$ The German cohort evaluated the frequency of antinuclear antibodies to $25 \%{ }^{52}$ In the ASSERT study, adverse events were reported by $82.2 \%$ of patients receiving infliximab and $72 \%$ receiving placebo. Forty-three percent of patients in the infliximab group reported infection compared with $36 \%$ in the placebo group. ${ }^{50}$

In all of these studies testing the efficacy of infliximab, there were no life-threatening events and no cases of malignancy. Considering the whole group of AS and SpA patients included in these clinical trials (total $=500$ ), serious infections such as tuberculosis occurred in only two cases.

In the systematic safety follow-up of the Ghent cohort including $107 \mathrm{SpA}$ patients treated with infliximab, corresponding to a total of 191.5 patient years, eight severe infections were observed, including two tuberculosis, three retropharyngeal abcesses, one extensive wound infection, one septic arthritis, and one unprecised sepsis. ${ }^{73}$

Risk of lymphoma is a serious preoccupation in patients receiving anti-TNF $\alpha$ agents. In rheumatoid arthritis, there is an increased risk for lymphoma development which is related to the disease activity. Whether this risk is increased 
by anti-TNF $\alpha$ treatment or not remains still debated. The risk for malignant lymphoma in AS has been evaluated in a population-based case control study conducted in Sweden. ${ }^{74}$ In this study and in the absence of anti-TNF $\alpha$ agents, patients hospitalized with AS do not show increased risk for lymphoma (relative risk [RR]: 1.0; 95\% CI: 0.6-1.7). In the different clinical trials with infliximab in AS and the long-term surveillance of these patients, a limited number of lymphoma were reported (four cases by the French threeyear prospective RATIO observatory). ${ }^{75,76}$ In addition, one exceptional case of lymphoma has been reported in a patient with AS treated by etanercept. ${ }^{77}$

\section{Impact of infliximab on extraarticular manifestations of ankylosing spondylitis}

Acute anterior uveitis occurs in $20 \%-30 \%$ of AS patients. Infliximab was shown to be effective in the treatment of acute onset HLA-B27 associated anterior uveitis ${ }^{78}$ and resistant SpA-related uveitis. ${ }^{79}$ During the clinical trials with infliximab in AS patients, a small proportion of patients developed acute uveitis under infliximab compared with patients in the placebo group. Using a registry-based study, the cases of uveitis occurring associated with the three available TNF $\alpha$-blocking agents (infliximab, etanercept, and adlimumab) were reviewed. After correction for the estimated number of cases treated by each treatment, the results showed that etanercept was associated with a greater number of uveitis than infliximab or adalimumab. ${ }^{80}$ Another study estimated the incidence of anterior uveitis in AS patients receiving infliximab or etanercept. Data were collected from placebo-controlled and open-label studies. ${ }^{81}$ The frequency of anterior uveitis was higher in patients receiving placebo compared to patients under antiTNF $\alpha$ agents (15.6 versus 6.8 per 100 patient-years). Of interest, flares of anterior uveitis occurred less frequently in patients treated with infliximab (3.4/100 patient-years) than in those treated with etanercept (7.9/100 patient-year), but the difference was not significant. Collectively, these data suggest that infliximab (and other TNF $\alpha$ blockers) is associated with a decrease incidence of anterior uveitis, a phenomenon that was more evident with the monoclonal antibodies.

Psoriasis may be associated with AS. A randomized placebo-controlled trial demonstrated that infliximab was effective in psoriatic arthritis and in the treatment of skin lesions of psoriasis. ${ }^{82,83}$

Infliximab, on the contrary of etanercept is effective in Crohn's disease. ${ }^{33}$ Patients with AS have subclinical gut involvement resembling Crohn's disease at a high frequency $(40 \%-60 \%)$. In this sense, infliximab is a treatment of choice for AS patient with concomitant Crohn's disease. A retrospective analysis of open-label and placebocontrolled trials evaluated the incidence of flares or new onset of IBD in patients with AS treated by anti-TNF $\alpha{ }^{84}$ Data were analyzed from 419 AS patients exposed to infliximab (618 patient-years) or etanercept (625 patientyears) or adalimumab (132 patient-years) and 434 placebo patients (150 patient-years). The results showed that new onset and flare of IBD were infrequent in patients receiving anti-TNF $\alpha$ agents. In addition, infliximab prevented better flare of IBD than etanercept. However, the incidence of new onset of IBD was statistically not different from placebo for all anti-TNF $\alpha$ agents.

\section{Current guidelines for initiating infliximab in ankylosing spondylitis}

Infliximab has been approved in the USA (in 2004) for reducing signs and symptoms in patients with active AS and in Europe (in 2003) for treatment in patients with severe axial AS and elevated laboratory parameters of inflammation and who are refractory to conventional treatments. Infliximab is also licensed for the treatment of Crohn's disease, rheumatoid arthritis, psoriatic arthritis, and psoriasis without arthritis. A relevant question is which patient can benefit from infliximab, a high-cost treatment?

In 2002, the ASAS working group proposed a consensus statement for the use of TNF $\alpha$ blockers in AS patients. ${ }^{85}$ These recommendations were updated in $2006^{86}$ and involved different levels concerning diagnosis, failure of standard treatments, disease activity, monitoring and criteria for withdrawal. Patients should respond to the modified New York criteria. Standard treatment failure corresponds to the trial of at least three months of standard NSAIDs, with at least two different NSAIDs. Failure of intraarticular joint corticosteroid injection and sulfasalazine for four months in the case of peripheral AS are required. For enthesopathic symptoms, failure of steroid injections is also required. Disease activity is defined based on the BASDAI, with a score higher than $4 / 10$. The disease must be active for at least four weeks and the expert opinion should be useful. For monitoring the patients, the following clinical variables must be recorded: patient assessment, pain, spinal mobility, BASDAI, BASFI, swollen joint count, and laboratory parameters of inflammation (ESR and CRP levels). There was an agreement to state that biologic agents should be discontinued in patients who do not have a $50 \%$ 
or a two-point absolute improvement in the BASDAI after 6-12 weeks. This consensus statement may be used as guidelines for clinical decision in initiating (or interrupting) anti-TNF $\alpha$ therapy in AS.

The Canadian rheumatology association has also proposed a consensus for infliximab (or etanercept) initiation, based upon literature analysis. Anti-TNF $\alpha$ agents are indicated for reducing signs and symptoms of AS with moderate to severe activity and inadequate response to maximal doses of at least two NSAIDs taken for three months and either sulfasalzine or methotrexate if the patient has peripheral arthritis. ${ }^{87}$

In France, the CRI (Club Rhumatismes et Inflammation), a subgroup of the French Society for Rheumatology, published in 2006 the guidelines for the use of anti-TNF $\alpha$ agents in patients with $\mathrm{AS}^{88}$ These guidelines were similar to the ASAS recommendations, but with some differences: three NSAIDS are required before considering the patient to be refractory to conventional treatments and patients without radiological sacroiliitis (required for satisfying the modified New York criteria) but with evidences of inflammation at the spine or sacroiliac joints documented by MRI may benefit from anti-TNF $\alpha$ agents.

In clinical practice, rheumatologists have their own opinion on the criteria for initiating anti-TNF $\alpha$ therapy. In a Dutch rheumatologist study, the more important variables for starting anti-TNF $\alpha$ in AS were rate of development of functional impairment, physician global assessment of disease activity, presence of hip arthritis, and physician global assessment of disease severity. ${ }^{89}$

In addition, patients with poor prognostic factors may be considered as reasonable candidates for anti-TNF $\alpha$ therapy and infliximab. Thus, the clinicians can use the prognostic factors for AS previously identified ${ }^{13,14}$ for screening the patients who could be treated by anti-TNF $\alpha$ agents.

Predictors of good response to anti-TNF $\alpha$ agents (infiximab and etanercept) have been identified by analyzing the results from randomized controlled trials: a short disease duration, a young age, a low BASFI, an elevated CRP, and a high BASDAI are predictor of a BASDAI improvement $>50 \% .^{90}$ In addition, MRI gives also insights in clinical response: spine and sacroiliac joint MRI from patients who participated in controlled studies were analyzed with respect to the presence or not of inflammatory lesions. The likelihood to achieve a BASDAI 50 response was found better in patients with a high MRI spinal score, a short disease duration, and a high CRP. ${ }^{91}$

However, these factors may help the physician to predict a good clinical response, but it does not mean that the initiation of infliximab or another TNF $\alpha$ antagonist may be restricted to these patients.

\section{Discussion}

Collectively, all these data strongly supports that infliximab is highly effective in the treatment of AS patients. This efficacy has been demonstrated in open-label and adequately designed placebo-controlled trials in the different aspects of the disease. Indeed, infliximab is effective in both spinal and peripheral manifestations, in sacroilitis or enthesitis, in reducing signs and symptoms of AS with an improvement of all ASAS core set (disease activity, function, pain, stiffness, quality of life), as well as laboratory parameters of inflammation or active inflammatory lesions detected on MRI. Clinical response is retained for up to five years with maintenance therapy. ${ }^{92}$

The global safety profile of infliximab seems favorable, but data are supported by a short-term use. Long-term surveillance data begins to be available but more time is needed to know the safety for a longer period of time (especially for a disease which will be treated as long as the treatment is effective and well tolerated). Currently, there are only a few cases of opportunistic infections that have been reported in AS under infliximab and lymphoma is also a rare complicating situation.

What are the pending questions with the use of infliximab in AS?

- What is the optimal interval of infusion? According to the clinical trials and the extension protocol studies, the recommended infliximab regimen is an intravenous infusion of $5 \mathrm{mg} / \mathrm{kg}$ at weeks 0,2 , and 6 , followed by maintenance infusions at six- or eight-week intervals. ${ }^{40,92}$

- What is the recommended infliximab dosage? Most studies evaluated the efficacy of infliximab in AS at a $5 \mathrm{mg} / \mathrm{kg}$ dosage. One study tried the medication at a lower dosage, $3 \mathrm{mg} / \mathrm{kg}$, with favorable results. ${ }^{44}$ However, in a small study involving six patients with $\mathrm{SpA}$, response to $3 \mathrm{mg} / \mathrm{kg}$ was inferior to $5 \mathrm{mg} / \mathrm{kg} .{ }^{93}$

- Do we need to associate methotrexate with infliximab in clinical practice? This question is relevant since anti-chimeric antibodies may occur with the use of infliximab. ${ }^{40}$ In RA, it is thought that methotrexate (MTX) reduces the incidence of anti-chimeric antibodies and this associated medication may lower the incidence of acute infusion reaction to infliximab and finally, prevent progressive loss of efficacy. However, we do not have proof that MTX may be useful in AS patients treated by infliximab. One randomized controlled trial conducted 
in the UK evaluated the response to MTX (7.5-10 mg weekly) + infliximab (5 mg/kg given at weeks $0,2,6$, and then at weeks 14 and 22) compared with MTX + placebo. A higher proportion of patient in the MTX + infliximab group reached an ASAS20 response compared to the MTX + placebo group ( $50 \%$ versus $21 \%$ ), and the association of MTX did not allow to prolong the response to infliximab. Indeed, in this study, due to a longer interval between infliximab infusions (eight weeks after the induction treatment regimen at weeks 0,2 , and 6), some patients had a flare of their disease. ${ }^{94}$ Another multicenter study conducted in France specifically evaluated the need for the patient to be treated continuously by infliximab or only in case of relapse, and the potential benefit of associated MTX treatment. 247 patients participated in this study: 124 received infliximab $(5 \mathrm{mg} / \mathrm{kg}$ ) every six weeks and 123 received on-demand treatment (based upon symptom recurrence). In this latter group, 62 patients received associated treatment with MTX and 61 infliximab alone. At week 58, a greater proportion of patients treated continuously achieved an ASAS20 response than patients in the on-demand group. The association of MTX to infliximab did not improve the proportion of ASAS20 responders. Thus, this study indicates that infliximab is more efficacious when administered continuously (every six weeks) and that the addition of MTX provides no substantial benefit. ${ }^{95}$

A third study in UK confirms these results: in a randomized placebo controlled study, 38 AS patients received either infliximab + MTX or infliximab + placebo. The ASAS 20 response did not differ between the two groups as well as the improvement in MRI spinal score. ${ }^{96}$

- Does infliximab have an impact on the structural progression of the disease? Infliximab may suppress active signs of inflammation on MRI, suggesting that the treatment has the potential to slow down the progression of the disease. In other words, infliximab could prevent the development of (new) syndesmophytes and therefore, has a structural effect. In fact, preliminary analysis suggests that inflixmab is capable to decelerate progression of spinal structural changes. In the German cohort, patients receiving infliximab for up to two and four years were scored for radiological changes using the modified Stokes Ankylosing Spondylitis Spinal Score (mSASSS) and were compared to published data from the historical OASIS cohort who had no prior use of anti-TNF $\alpha$ agents. ${ }^{97}$ The results showed that the rate of progression of the mSASSS score in patients under infliximab was lower compared to patients from the OASIS cohort (mean mSASSS changes over four years in the infliximab patients were $1.6 \pm 2.6$ units compared to 4.4 units in OASIS). As previously described, patients who have definite changes at baseline developed more chronic changes than those without damage at baseline. However, if the change of the mean mSASSS in comparison with baseline was significantly different at two years of follow-up, this difference did not persist after four years. Collectively, and although there is no adequate control group in this study, these data suggest that infliximab has the potential to decelerate the progression of spinal structural damage in AS.

However, these data were not confirmed by another radiographic analysis from the patients of the ASSERT trial. ${ }^{98}$ In this randomized placebo-controlled study (including 279 AS patients), 201 had radiographic analyses at baseline and after two years of infliximab therapy. The radiographic findings (assessed by the mSASSS) of these patients were compared to those from the OASIS cohort. After two years, the median or the mean change of the mSASSS score did not differ between the two patient populations, suggesting that infliximab has no effect on the progression of the disease. Again, there is no true control group in this study. In addition, the mSASSS evaluates structural damage at the cervical and lumbar spine, without considering the thoracic spine which is the preferential level of syndesmophyte development. And finally, the mSASSS score has a low sensitivity to changes and a minimal period of two years is required to appreciate a radiological progression. For all these reasons, the radiographic analysis from the ASSERT study (and from the German cohort) is to interpret with caution.

- Infliximab is associated with paradoxal and unexplained effects:

- Infliximab is approved in the treatment of psoriasis and psoriatic arthritis. However, there are some unexpected reports of exacerbation or new onset of psoriasis in patients who had previously no skin disease. This paradoxal effect has been described with the three available anti-TNF $\alpha$ including infliximab. 120 cases were recently reviewed. The prevalence of this phenomenon has been estimated to range between $1.5 \%$ to $5 \%$ of patients treated by $\mathrm{TNF} \alpha$ antagonists. Underlying diseases may be AS, psoriatic arthritis, RA, or Crohn's disease. 
The clinical features included psoriasis, palmo-plantar pustular lesions, psoriasis of the nail or psoriasiform exanthema. The delay between initiation of the antiTNF $\alpha$ agent and appearance of skin lesions varied from the first administration to 63 months. Various outcome were reported after cessation or switching the TNF $\alpha$ antagonist, with or without anti-psoriatic adjuvant therapy. The underlying pathomechanisms of these psoriasis-induced lesions remain unclear and certainly involved different factors (infection, change in cytokine balance).$^{99}$

- Infliximab is effective in the treatment of Crohn's disease. However, there are exceptional cases of Crohn's disease development in AS patients receiving etanercept. ${ }^{100-102}$ but also infiximab (Toussirot, personnal observation). However, one may remark that the introduction of the TNF $\alpha$ blockers may demask an undiagnosed but underlying IBD in these patients who are predisposed to have inflammation of the gut.

- Finally, various non infectious granulomatous diseases have been described in patients with AS or RA with the use of TNF $\alpha$ antagonists such as sarcodiosis, mainly with etanercept but also infliximab. ${ }^{103,104}$

\section{Conclusion}

Infliximab is effective in the treatment of active AS and has demonstrated in the short term and medium term, significant improvements of signs and symptoms of AS. Some questions persist such as the real impact of this treatment on the progression of radiological damage. On the contrary of NSAIDs, ${ }^{105}$ the results of the published studies failed to demonstrate such an effect and thus, we cannot currently consider infliximab (and other TNF $\alpha$ antagonists as well) as a disease-controlling anti-rheumatic therapy. Nevertheless, due to the high level of efficacy obtains in the different domains of the disease, infliximab represents undoubtedly a considerable advancement in the therapeutic management of AS, and this medication has "really changed the life of the patients."

\section{Disclosure}

The authors report no conflicts of interest in this work.

\section{References}

1. Van Der Linden S, Van Der Heijde D. Ankylosing spondylitis. Clinical features. Rheum Dis Clin North Am. 1998;24(4):663-676.

2. Calin A. Terminology, introduction, diagnostic criteria, and overview. In: The Spondylarthritides. Calin A, Taurog JD, editors. Oxford, UK: Oxford University Press; 1998. p. 1-15.
3. Braun J, Bollow M, Neure L, et al. Use of immunohistologic and in situ hybridization techniques in the examination of sacroiliac joint biopsy specimens from patients with ankylosing spondylitis. Arthritis Rheum. 1995;38(4):499-505.

4. Laloux L, Voisin MC, Allain J, et al. Immunohistological study of entheses in spondylarthropathies: comparison in rheumatoid arthritis and osteoarthritis. Ann Rheum Dis. 2001;60(4):316-321.

5. Baeten D, Demetter P, Cuvelier C, et al. Comparative study of the synovial histology in rheumatoid arthritis, spondylarthropathy, and osteoarthritis: influence of disease duration and activity. Ann Rheum Dis. 2000;59(12):945-953.

6. Appel H, Kuhne M, Spiekermann, et al. Immunohistologic analysis of zygapophyseal joints in patients with ankylosing spondylitis. Arthritis Rheum. 2006;54(9):2845-2851.

7. Brown MA, Kennedy LG, Macgregor AJ, et al. Susceptibility to ankylosing spondylitis in twins: the role of genes, HLA, and the environment. Arthritis Rheum. 1997;40(10):1823-1828.

8. Sims AM, Timms AE, Bruges-Armas J, et al. Prospective meta-analysis of interleukin-1 gene complex polymorphisms confirms association with ankylosing spondylitis. Ann Rheum Dis. 2008;67(9):1305-1309.

9. Rahman P, Inman RD, Gladman DD, et al. Association of IL-23 receptor variants with ankylosing spondylitis. Arthritis Rheum. 2008(4);58:1020-1225.

10. Braun J, Bollow M, Remlinger G, et al. Prevalence of spondylarthropathies in HLA-B27 positive and negative blood donors. Arthritis Rheum. 1998;41(1):58-67.

11. Saraux A, Guillemin F, Guggenbuhl, et al. Prevalence of spondylarthropthies in France: 2001. Ann Rheum Dis. 2005;64(10):1431-1435.

12. Little $\mathrm{H}$. The natural history of ankylosing spondylitis. $J$ Rheumatol. 1988; 15:1179-1180.

13. Gran JT, Skomsvoll JF. The outcome of ankylosing spondylitis: a study of 100 patients. Br J Rheumatol. 1997;36(7):766-771.

14. Amor B, Santos RS, Nahal R, Listrat V, Dougados M. Predictive factors for the long term outcome of spondylarthropathies. J Rheumatol. 1994;21(10):1883-1887.

15. Braun J, Pincus T. Mortality, course of the disease and prognosis of patients with ankylosing spondylitis. Clin Exp Rheumatol. 2002; 20(Suppl 28):S16-S22.

16. Van Der Heijde D, Calin A, Dougados M, et al. Selection of instruments in the core set for DC-ART, SMARD, physical therapy, and clinical record keeping in ankylosing spondylitis. Progress report of the ASAS working group. J Rheumatol. 1999;26(4):951-954.

17. Anderson JJ, Baron G, Van Der Heijde D, Felson DT, Dougados M. Ankylosing spondylitis assessment group preliminary definition of short-term improvement in ankylosing spondylitis. Arthritis Rheum. 2001;44(8):1876-1886.

18. Gran JT, Husby G. Ankylosing spondylitis. Current drug treatment. Drugs. 1992;44(4):585-603.

19. Toussirot E, Wendling D. Current guidelines for the drug treatment of ankylosing spondylitis. Drugs. 1998;56(2):225-240.

20. Toussirot E. Management of ankylosing spondylitis and related spondylarthritis: established treatments, new pharmacological options and anti-TNFalpha therapies. In: Colombus F, editor. Arthritis Research. Houston, TX: Nova Science Publishers; 2005.

21. Van Tubergen A, Landewe R, Van Der Heijde D, et al. Combined spa-exercise is effective in patients with ankylosing spondylitis: a randomized controlled trial. Arthritis Rheum. 2001;45(5):430-438.

22. Calin A, Elswood J. A prospective nationwide cross-sectional study of NSAID usage in 1331 patients with ankylosing spondylitis. J Rheumatol. 1990;17(6):801-803.

23. Clegg DO, Reda DJ, Abdellatif M. Comparison of sulfasalazine and placebo for the treatment of axial and peripheral articular manifestations of seronegative spondylarthropathies. A Department of Veterans Affairs Cooperative Study. Arthritis Rheum. 1999;42(11):2325-2329.

24. Gonzalez-Lopez L, Garcia-Gonzalez A, Vazquez-Del-Mercado M, Muniz-Valle JF, Gamez-Nava JI. Efficacy of methotrexate in ankylosing spondylitis. A randomized placebo controlled trial. J Rheumatol. 2004; 31(8):1568-1574. 
25. Van Denderen JC, Van der Paardt M, Nurmohamed MT, de Ryck YM, Dijkmans BA, van der Horts-Bruinsma IE. Double-blind,randomized, placebo-controlled study of leflunomide in the treatment of active ankylosing spondylitis. Ann Rheum Dis. 2005;64(12):1761-1764.

26. Haibel H, Rudwaleit M, Listing J, Sieper J. Open label trial of anakinra in active ankylosing spondylitis over 24 weeks. Ann Rheum Dis. 2005;64(2):296-298.

27. Maksymowych WP, Jhangri GS, Fitzgerald AA, et al. A six-month randomized, controlled, double-blind, dose response comparison of intravenous pamidronate $(60 \mathrm{mg}$ versus $10 \mathrm{mg}$ ) in the treatment of nonsteroidal antiinflammatory drug-refractory ankylosing spondylitis. Arthritis Rheum. 2002;46(3):766-773.

28. Toussirot E, Le Huédé G, Lohse A, Cedoz JP, Wendling D. Transcient efficacy of pulse pamidronate treatment in active spondylarthropathies: an open study of 35 cases. Clin Exp Rheumatol. 2006; 24(3):348.

29. Maugars Y, Mathis C, Berthelot JM, et al. Assessment of the efficacy of sacroiliac corticosteroid injections in spondylarthropathies: a double blind study. Br J Rheumatol. 1996;35(8):767-770.

30. Gratacos J, Collado A, Filella X, et al. Serum cytokines (IL-6, TNF $\alpha$, IL-1 $\beta$ and IFN $\gamma$ ) in ankylosing spondylitis: a close correlation between serum IL-6 and disease activity and severity. Br J Rheumatol. 1994;33(10):927-931.

31. Toussirot E, Lafforgue P, Boucraut J, et al. Serum levels of IL-1 $\beta$, TNF $\alpha$, soluble IL-2 receptor and soluble CD8 in seronegative spondylarthropathies. Rheumatol Int. 1994;13(5):175-180.

32. Mielants H, Veys EM. HLA-B27 related arthritis and bowel inflammation: sulfasalazine in HLA-B27 related arthritis. $J$ Rheumatol. 1985;12(2):287-293.

33. Sandborn WJ. Anti-tumor necrosis factor therapy for inflammatory bowel disease: a review of agents, pharmacology, clinical results and safety. Inflamm Bowel Dis. 1999;5(2):119-133.

34. Breban M, Gombert B, Amor B, Dougados M. Efficacy of thalidomide in the treatment of refractory ankylosing spondylitis. Arthritis Rheum. 1999;42(3):580-581.

35. Sieper J, Braun J. New treatment options in ankylosing spondylitis: a role for anti-TNF $\alpha$ therapy. Ann Rheum Dis. 2001;60(Suppl 3): iii58-61.

36. Van Den Bosch, Baeten D, Kruithof E, De Keyser F, Mielants H, Veys EM. Treatment of active spondylarthropathy with infliximab, the chimeric monoclonal antibody to tumor necrosis factor $\alpha$. Ann Rheum Dis. 2001;60(Suppl 3):iii33-66.

37. Toussirot E, Wendling D. Recent progress in ankylosing spondylitis. Expert Opin Pharmacother. 2003;4(1):1-12.

38. Wendling D, Toussirot E. Anti-TNF $\alpha$ therapy in ankylosing spondylitis. Expert Opin Pharmacother. 2004;5(7):1497-1507.

39. Markham A, Lamb HM. Infliximab. A review of its use in the management of rheumatoid arthritis. Drugs. 2000;59(6):1341-1359.

40. Robinson DM, Keating GM. Infliximab in ankylosing spondylitis. Drugs. 2005;65(9):1283-1291.

41. Brandt J, Haibel H, Cornely D, et al. Successful treatment of active ankylosing spondylitis with the anti-tumor necrosis factor $\alpha$ monoclonal antibody infliximab. Arthritis Rheum. 2000;43(6):1346-1352.

42. Van Der Bosch F, Kruithof E, Baeten D, De Keyser F, Mielants H, Veys EM. Effects of a loading dose regimen of three infusions of chimeric monoclonal antibody to tumor necrosis factor $\alpha$ (infliximab) in spondylarthropathy: an open pilot study. Ann Rheum Dis. 2000;59(6):428-433.

43. Stone M, Salonen D, Lax M, et al. Clinical and imaging correlates of response to treatment with infliximab in patients with ankylosing spondylitis. $J$ Rheumatol. 2001;28(7):1605-1614.

44. Maksymowych W, Jhangri GS, Lambert RG, et al. Infliximab in ankylosing spondylitis: a prospective observational inception cohort analysis of efficacy and safety. J Rheumatol. 2002;29(5):959-965.

45. Breban M, Vignon E, Claudepierre $P$, et al. Efficacy of infliximab in refractory ankylosing spondylitis: results of a six-month open-label study. Rheumatology. 2002;41(11):1280-1285.
46. Temekonidis TI, Alamanos Y, Nikas SN, et al. Infliximab therapy in patients with ankylosing spondylitis: an open label 12 month study. Ann Rheum Dis. 2003;62(12):1218-1220.

47. Collantes-Estevez E, Munoz-Villanueva MC, Canete-Crespillo, et al. Infliximab in refractory spondylarthropathies: a multicentre 38 week open study. Ann Rheum Dis. 2003;62(12):1239-1240.

48. Braun J, Brandt J, Listing J, et al. Treatment of active ankylosing spondylitis with infliximab: a randomized controlled multicentre trial. Lancet. 2002;359(9313):1187-1193.

49. Van Den Bosch F, Kruithof E, Baeten D, et al. Randomised double blind comparison of chimeric monoclonal antibody to tumor necrosis factor alpha (infliximab) versus placebo in active spondylarthropathy. Arthritis Rheum. 2002;46(3):755-765.

50. Van der Heijde D, Dijkmans B, Geusens P, et al. Efficacy and safety of infliximab in patients with ankylosign spondylitis. Results of a randomized, placebo-controlled trial (ASSERT). Arthritis Rheum. 2005;52(2):582-591.

51. Kruithof E, Van Den Bosch F, Baeten D, et al. Repeated infusions of infliximab, a chimeric anti-TNF $\alpha$ monoclonal antibody in patients with active spondylarthropathy: one year follow up. Ann Rheum Dis. 2002;61(3):207-212.

52. Braun J, Brandt J, Listing J, et al. Long-term efficacy and safety of infliximab in the treatment of ankylosing spondylitis. An open, observational, extension study of a three month, randomized, placebo-controlled trial. Arthritis Rheum. 2003;48(8):2224-2233.

53. Braun J, Baraliakos X, Golder W, et al. Magnetic resonance imaging examinations of the spine, before and after successful therapy with infliximab: evaluation of new scoring system. Arthritis Rheum. 2003; 48(4):1126-1136.

54. D’Agostino MA, Breban M, Said-Nahal R, Dougados M. Refractory inflammatory heel pain in spondylarthropathy: a significant response to infliximab documented by ultrasound. Arthritis Rheum. 2002;46(3):840-841.

55. Toussirot E, Wendling D. Bone mass in ankylosing spondylitis. Clin Exp Rheumatol. 2000;18(Suppl 21):S16-S20.

56. Allali F, Breban M, Porcher R, Maillefert JF, Dougados M, Roux C. Increase in bone mineral density of patients with spondylarthropathy treated with anti-tumour necrosis factor-alpha. Ann Rheum Dis. 2003;62(4):347-349.

57. Keller C, Webb A, Davis J. Cytokines in the seronegative spondylarthropathies and their modification by TNF blockade: a brief report and literature review. Ann Rheum Dis. 2003;62(12):1128-1132.

58. Zou J, Rudwaleit M, Brandt J, et al. Down-regulation of the nonspecific and antigen specific $\mathrm{T}$ cell cytokine response in ankylosing spondylitis during treatment with infliximab. Arthritis Rheum. 2003;48(3): 780-790.

59. Zou J, Braun J, Sieper J. Immunological basis for the use of TNF $\alpha$ blocking agents in ankylosing spondylitis and immunologic changes during treatment. Clin Exp Rheumatol. 2002;20(Suppl 28):S34-S37.

60. Baeten D, Van Damme N, Van Den Bosch F, et al. Impaired Th1 cytokine production in spondylarthropathy is restored by anti-TNF $\alpha$. Ann Rheum Dis. 2001;60(8):750-755.

61. Yang $\mathrm{C}, \mathrm{Gu} J$, Rihl M, et al. Serum levels of matrix metalloproteinase 3 and macrophage colony-stimulating factor 1 correlate with disease activity in ankylosing spondylitis. Arthritis Rheum. 2004;51(5):691-699.

62. Maksymowych W, Landewé R, Conner-Spady B, et al. Serum matrix metalloproteinase 3 is an independent predictor of structural damage progression in patients with ankylosing spondylitis. Arthritis Rheum. 2007;56(6):1846-1853.

63. Vandooren B, Kruithof E, Yu DT, et al. Involvement of matrix metalloproteinases and their inhibitors in peripheral synovitis and down-regulation by tumor-necrosis factor alpha blockade in spondylarthropathy. Arthritis Rheum. 2004;50(9):2942-2953.

64. Baeten D, Kruithof E, Van Den Bosch F, et al. Immunomodulatory effects of anti-tumor necrosis factor $\alpha$ therapy on synovium in spondylarthropathy. Arthritis Rheum. 2001;44(1):186-195. 
65. Braun J, Brandt J, Listing J, et al. Two year maintenance of efficacy and safety of infliximab in the treatment of ankylosing spondylitis. Ann Rheum Dis. 2005;64(2):229-234.

66. Braun J, Baraliakos X, Brandt J, et al. Persistent clincial response to the anti-TNF-alpha antibody infliximab in patients with ankylosing spondylitis over 3 years. Rheumatology. 2005;44(5):670-676.

67. Braun J, Baraliakos X, Listing J, et al. Persistent clinical efficacy and safety of anti-tumor necrosis factor alpha therapy with infliximab in patients with ankylosing spondylitis over 5 years: evidence for different types of response. Ann Rheum Dis. 2008;67(3):340-345.

68. Braun J, Deodhar A, Dijkmans B, et al. Efficacy and safety of infliximab in patients with ankylosing spondylitis over a two-year period. Arthritis Rheum. 2008;59(9):1270-1278.

69. Venetsanopoulos AI, Vougari PV, Alamanos Y, Papadopoulos CG, Markatseli TE, Drosos AA. Persistent clinical response of infliximab treatment over a 4 year period in ankylosing spondylitis. Rheumatol Int. 2007;27(10):935-939.

70. Nikkas SN, Alamanos Y, Voulgari PV, Pliakou XI, Papadopoulos CG, Drosos AA. Infliximab therapy in ankylosing spondylitis: an observational study. Ann Rheum Dis. 2005;64:940-942.

71. Gossec L, Le Henanff A, Breban M, et al. Continuation of treatment with infliximab in ankylosing spondylitis: 2 year open follow up. Rheumatology. 2006;45(7):859-862.

72. Khanna D, McMahon M, Furst DE. Safety of tumour necrosis factoralpha antagonists. Drug Saf. 2004;27(5):301-324.

73. Baeten D, Kruithof E, Van Den Bosch F, et al. Systematic safety follow up in a cohort of 107 patients with spondylarthropathy treated with infliximab: a new perspective on the role of host defence in the pathogenesis of the disease? Ann Rheum Dis. 2003;62(9): 829-834.

74. Askling J, Klareskog L, Blomqvist P, Fored M, Feltelius N. Risk of malignant lymphoma in ankylosing spondylitis: a nationwide Swedish case-control study. Ann Rheum Dis. 2006;65(9):1184-1187.

75. Tubach F, Salmon-Céron D, Ravaud P, Mariette X; for the RATIO Study Group. The RATIO observatory: French registry of opportunistic infections, severe bacterial infections, and lymphoma complicating anti-TNFalpha therapy. Joint Bone Spine. 2005;72(12):456-460.

76. Mariette X, Tubach F, Ravaud $\mathrm{P}$, et al. The risk of lymphoma is higher in patients treated with infliximab or adalimumab than in patients treated with etanercept. Results of the French 3-year prospective Ratio observatory. Arthritis Rheum. 2008;58(Suppl):S782.

77. Aksu K, Donmez A, Ertan Y, et al. Hodgkin's lymphoma following treatment with etanercept in ankylosing spondylitis. Rheumatol Int. 2007;28(2):185-187.

78. El-Shabrawi Y, Hermann J. Anti-tumor necrosis factor-alpha therapy with infliximab as an alternative to corticosteroids in the treatment of human leukocyte antigen B27 associated acute anterior uveitis. Ophtalmology. 2002;109(12):2342-2346.

79. Kruithof E, Kestelyn P, Elewaut C, et al. Successful use of infliximab in a patient with treatment resistant spondylarthropathy related uveitis. Ann Rheum Dis. 2002;61(5):470.

80. Lim LL, Fraunfelder FW, Rosenbaum JT. Do tumor necrosis factor inhibitors cause uveitis? A registry-based study. Arthritis Rheum. 2007;56(10):3248-3252.

81. Braun J, Baraliakos X, Listing J, Sieper J. Decreased incidence of anterior uveitis in patients with ankylosing spondylitis treated with the anti-tumor necrosis factor agents infliximab and etanercept. Arthritis Rheum. 2005;52(8):2447-2451.

82. Antoni CE, Kavanaugh A, Kirkham B, et al. Sustained benefits of infliximab therapy for dermatologic and articular manifestations of psoriatic arthritis: results from the infliximab multinational psoriatic arthritis controlled trial (IMPACT). Arthritis Rheum. 2005;52(4): 1227-1236.

83. Antoni C, Krueger GG, de Vlam K, Infliximab improves signs and symptoms of psoriatic arthritis: results of the IMPACT 2 trial. IMPACT 2 Trial Investigators. Ann Rheum Dis. 2005;64(8):1150-1157.
84. Braun J, Baraliakos X, Listing J, Davis J, Van der Heijde D, Haibel H, et al. Differences in the incidence of flares or new onset of inflammatory bowel diseases in patients with ankylosing spondylitis exposed to therapy with anti-tumor necrosis factor alpha agents. Arthritis Rheum. 2007;57(4):639-647.

85. Braun J, Pham T, Sieper J, et al. International ASAS consensus statement for the use of anti-tumor necrosis factor agents in patients with ankylosing spondylitis. Ann Rheum Dis. 2003;62(9):817-824.

86. Braun J, Davis J, Dougados M, Sieper J, van der Linden S, van der Heijde D; ASAS Working Group. First update of the international ASAS consensus statement for the use of anti-TNF agents in patients with ankylosing spondylitis. Ann Rheum Dis. 2006;65(3): 316-320.

87. Maksyowych W, Inman RD, Gladman D, et al. Canadian Rheumatology association consensus on the use of anti-tumor necrosis factor alpha directed therapies in the treatment of spondylarthritis. J Rheumatol. 2003;30(6):1356-1363.

88. Pham T, Fautrel B, Dernis E, et al. Recommendations of the French Society for Rheumatology regarding TNFalpha antagonist therapy in patients with ankylosing spondylitis or psoriatic arthritis: 2007 update. Joint Bone Spine. 2007;74(12):638-646.

89. Landewé R, Rump B, Van Der Heijde D, et al. Which patients with ankylosing spondylitis should be treated with tumour necrosis factor inhibiting therapy? A survey among Dutch rheumatologists. Ann Rheum Dis. 2004;63(5):530-534.

90. Rudwaleit M, Listing J, Brandt J, et al. Prediction of a major clinical response (BASDAI) to tumour necrosis factor $\alpha$ blockers in ankylosing spondylitis. Ann Rheum Dis. 2004;63(6):665-670.

91. Rudwaleit M, Schwarzlose S, Hilgert ES, Listing J, Braun J, Sieper J. MRI in predicting a major clinical response to anti-tumor necrosis factor treatment in ankylosing spondylitis. Ann Rheum Dis. 2008; 67(9):1276-1281.

92. Rudwaleit M, Sieper J. Infliximab for the treatment of ankylosing spondylitis. Expert Opin Biol Ther. 2005;5(8):1095-1109.

93. Brandt J, Haibel H, Reddig J, Sieper J, Braun J. Successful treatment of severe undifferenciated spondylarthropathy with the anti-tumor necrosis factor alpha monoclonal antibody infliximab. J Rheumatol. 2002;29(1):118-122.

94. Marzo-Ortega H, McGonagle D, Jarrett S, et al. Infliximab in combination with methotrexate in active ankylosing spondylitis. A clinical and imaging study. Ann Rheum Dis. 2005;64(11):1568-1575.

95. Breban M, Ravaud P, Claudepierre P, et al. Maintenance of infliximab treatment in ankylosing spondylitis: results of a one-year randomized controlled trial comparing systematic versus on-demand treatment. Arthritis Rheum. 2008;58(1):88-97.

96. Li EK, Griffith JF, Lee VW, et al. Short-term efficacy of combination methotrexate and infliximab in patients with ankylosing spondylitis: a clinical and magnetic resonance imaging correlation. Rheumatology. 2008;47(9):1358-1353.

97. Baraliakos X, Listing J, Brandt J, et al. Radiographic progression in patients with ankylosing spondylitis after 4 years of treatment with the anti-TNFalpha antibody infliximab. Rheumatology. 2007;46(9): $1450-1453$.

98. Van der Heijde D, Landewé R, Baraliakos X, et al. Radiographic findings following two years of infliximab therapy in patients with ankylosing spondylitis. Arthritis Rheum. 2008;58(10): 3063-3070.

99. Wollina U, Hansel G, Koch A, Schönlebe J, Köstler E, Haroske G Tumor necrosis factor alpha inhibitor induced psoriasis or psoriasiform exanthema: first 120 cases from the literature including series of six new patients. Am J Clin Dermatol. 2008;9(1):1-14.

100. Oh J, Arkfeld DG, Horwitz DA. Development of Crohn's disease in a patient taking etanercept. J Rheumatol. 2005;32(4):752-753.

101. Song IH, Appel H, Haibel H, et al. New onset of Crohn's disease during treatment of active ankylosing spondylitis with etanercept. J Rheumatol. 2008;35(3):532-536. 
102. Yazisiz V, Avci AB, Erbasan F, Yildirim B, Terzioglu E. Development of Crohn's disease following anti-tumour necrosis factor therapy (etanercept). Colorectal Dis. 2008;10(9):953-954.

103. Toussirot E, Pertuiset E, Kantelip B, Wendling D. Sarcoidosis occuring during anti-TNFalpha treatment for inflammatory rheumatic diseases: report of two cases. Clin Exp Rheumatol. 2008;26(3):461-475.

104. Daien CI, Monnier A, Claudepierre P, et al; for the Club Rhumatismes et Inflammation (CRI). Sarcoid-like granulomatosis in patients treated with tumor necrosis factor blockers: 10 cases. Rheumatology (Oxford). 2009; May 7 [Epub ahead of print].
105. Wanders A, Van Der Heijde D, Landewé R, et al. Non steroidal antiinflammatory drugs reduce radiographic progression in patients with ankylosing spondylitis: a randomized clinical trial. Arthritis Rheum. 2005;42(6):1756-1765.

\section{Publish your work in this journal}

Open Access Rheumatology Research and Reviews is an international, peer-reviewed, open access journal, publishing all aspects of clinical and experimental rheumatology in the clinic and laboratory including the following topics: Pathology, pathophysiology of rheumatological diseases; Investigation, treatment and management of rheumatological diseases; Clinical trials and novel pharmacological approaches for the treatment of rheumatological disorders. The manuscript management system is completely online and includes a very quick and fair peerreview system, which is all easy to use. Visit http://www.dovepress.com/ testimonials.php to read real quotes from published authors. 